\title{
Community challenges when using large plastic bottles for Solar Energy Disinfection of Water (SODIS)
}

Preeti Borde ${ }^{1}$, Khalifa Elmusharaf², Kevin G. McGuigan ${ }^{3}$ and Michael B. Keogh ${ }^{\text {* }}$

\begin{abstract}
Background: Communities living in developing countries as well as populations affected by natural or man-made disasters can be left at great risk from water related diseases, especially those spread through the faecal-oral route. Conventional water treatments such as boiling and chlorination can be effective but may prove costly for impoverished communities. Solar water disinfection (SODIS) has been shown to be a cheap and effective way for communities to treat their water. The exposure to sunlight is typically carried out in small volume plastic beverage bottles (up to 2 I). Given the water requirements of consumption and basic personal hygiene, this may not always meet the needs of communities. Recent work has shown 19-L plastic water dispenser containers to be effective SODIS reactors, comparable in efficacy to PET bottles. In this paper we outline the need for studying SODIS in large volumes and discuss 4 main associated challenges.
\end{abstract}

Discussion: Apart from clean water needed for consumption, access to adequate water is essential for sanitation and hygiene. Contamination of treated water through unwashed hands or vessels contributes heavily to the spread of water borne pathogens in communities. Traditional water treatments such as boiling and chlorination can be effective but may prove financially burdensome for low income communities. SODIS in large vessels could be used as a simple method to meet water requirements in low income and disaster affected populations. However, there have been some concerns associated with the conventional SODIS method; we identify the main ones to be: (1) cold or cloudy weather; (2) the fear of leaching in plastic bottles; (3) water turbidity, and; (4) community acceptance.

Summary: The application of SODIS in large bottles like WDCs has the potential to be an efficient and cost effective method of disinfecting water, either for consumption until more rigorous water treatments can be put in place, or for sanitation and hygiene to curb the spread of fecal contamination. Further research is needed that can address some of the limitations and challenges associated with the use of large bottles for SODIS.

Keywords: SODIS, Scale-up, Community implementation

Abbreviations: ADI, Acceptable daily intake; BPA, Bisphenol A; CDC, Centers for Disease Control and Prevention; EAWAG, Swiss Federal Institute of Aquatic Science and Technology; EDI, Estimated dietary intake; EFSA, European Food Safety Authority; FDA, Food and Drug Administration; IDMC, International Displacement Monitoring Centre; PC, Polycarbonate; PET, Polyethylene terephthalate; SODIS, Solar water disinfection; TDI, Tolerable daily intake; UNHCR, United Nations High Commissioner for Refugees; UNWRA, United Nations Relief and Works Agency for Palestine Refugees in the Near East; WDC, Water dispenser container; WHO, World Health Organization

\footnotetext{
* Correspondence: michaelkeogh_2000@yahoo.com

${ }^{1}$ Department of Basic Biomedical Sciences, RCSI, Manama, Bahrain

Full list of author information is available at the end of the article
} 


\section{Background}

The World Health Organization (WHO) estimates that around $10 \%$ of the global burden of disease can be attributed to lack of adequate drinking water, poor hygiene, and inefficient sanitation [1]. Unsafe water is the main reason for diarrheal diseases such as dysentery and cholera, preventable and treatable disorders which claim the lives of around 1.5 million people every year, around 760,000 of these being children under 5 years [2]. Water treatment techniques such as filtration, boiling, chlorination and ultra violet radiation, while effective may be too costly to use in developing countries or emergency situations. Solar water disinfection (SODIS) is a simple and cheap method which uses natural sunlight to treat contaminated water filled into transparent plastic containers and exposed to direct sunlight for up to $6 \mathrm{~h}$. SODIS has conventionally been implemented using 1-2 L polyethylene terephthalate (PET) bottles which have shown good characteristics of microbiological inactivation in natural sunlight [3-6]. To date, most SODIS based research has focused on using these 2 L PET bottles $[5,7,8]$.

The aim of this debate article is to identify the needs for SODIS in large volume bottles as well as to debate their limitations. The findings of this article will help to inform the global conversations around access to clean and safe water in resource-limited settings and to help develop appropriate and sustainable strategies at community level to enhance compliance with SODIS.

\section{Discussion}

\section{What is the Need for SODIS in Large Volumes?}

SODIS success stories are described from many groups under various field conditions, all of which strengthen solar water disinfection's position as a sustainable, cost effective method of acquiring clean drinking water in developing countries [9-11]. The impact on health of consumers of SODIS treated water has been closely followed in several countries such as Kenya, India and Cameroon and the data is encouraging with decreases in prevalence of diarrhea and other water borne diseases being reported among the intervention groups [12-14].

Unfortunately, the capacities of commercial PET bottles, which usually come in sizes that can hold up to $2 \mathrm{~L}$ of water, make them less suitable for disinfecting large quantities of water unless a number are put to use at the same time. This limits its sustained everyday use as a water treatment method owing mainly to the time and effort associated with setting up and keeping track of multiple SODIS bottles. This is an unfortunate restriction as SODIS holds several advantages over other treatment interventions such as boiling and chlorination in that apart from being low cost and easy to implement, it also uses up a minimal amount of consumables [3].
According to humanitarian agencies, it has been estimated that water requirements for consumption and hygiene based on basic survival needs are 7.5-15 l per person per day dependent on climate, sanitation facilities, social and cultural norms etc. [15]. We recently showed 191 polycarbonate (PC) Water dispenser containers (WDCs) were as effective at SODIS treatment for $E$. coli or E. faecalis as 2 L PET bottles [16]. These larger water containers could be valuable in emergency settings as well as to impoverished communities.

\section{Community needs}

A large body of research has highlighted the strong link between improvements in sanitation, simple personal hygiene and interventions to improve water quality at point of use with a decrease in diarrhea and other gastrointestinal diseases [17-20]. Boiling dominates the household water treatment landscape in resourcelimited settings with data from a 67 country survey reporting more than $21 \%$ of households preferring this method. Other practices included filtration, solar disinfection and the use of bleach or chlorine products [21]. In low-income communities, the improper handling and storage of water post treatment plays a large part in spreading water borne pathogens. In Peru for example, researchers looked at the fecal contamination of drinking water at different stages between the source and final consumption point. This work was carried out in a peri urban setting with chlorination at the main water outlets and household boiling. It was found that despite water at the source showing no microbiological contamination and boiling water before storage, almost a third of household samples from stored boiled water showed fecal contamination. This makes sense in the light of the fact that data collected on E.coli counts from the hands of users as well as from the cups residents used to pour water into before consumption showed high levels of bacterial contamination [22]. This decrease in quality of water between the collection at source and consumption has been seen in other community studies in countries like Brazil [23], Bolivia [24] and India [25] with factors like scooping water from containers with dirty hands, contamination during cleaning the storage vessel and the type of vessel used implicated as contributors to water contamination. Such studies highlight the importance of practices such as hand washing when collecting, handling and storing water. Obtaining enough quantities of clean water for hygiene and sanitation through methods like boiling or use of chlorine agents may prove expensive as well as time consuming [25]. The exposure of contaminated water to sunlight has consistently been shown to improve its quality and SODIS has so far primarily been used as a simple and cheap method to disinfect water for drinking. SODIS water treated in 
large bottles such as in WDCs can also be used to carry out hand and vessel washing in situations where the needs of drinking water are being met by other costlier methods. This can help to decrease the instances of recontamination of treated water in communities.

\section{Emergency settings}

In areas that have been struck by natural disasters or in refugee and disaster relief camps, the burden of providing necessary amounts of clean water falls on the local government and/or on aid organizations dealing with the crisis. It has been well established that provision of clean water for drinking is a critical factor in preventing morbidity and mortality in emergency settings [26]. However, it is worth noting that an equally important factor is an adequate quantity of clean water [27]. In light of the increased risk of susceptibility to diseases, the Sphere Project recommends that, following a disaster the provision of adequate quantities of water to the affected population takes precedence over access to high quality water until arrangements can be made to fulfil all minimum requirements [15].

According to the United Nations High Commissioner for Refugees (UNHCR), at the end of 2015 there were an estimated 21.3 million refugees worldwide [28]. A large percentage of these people live for varying amounts of time in over-crowded quarters in relief camps where basic water, sanitation and hygiene (WASH) practices can be severely compromised. As a result of such living conditions where the quantity of clean water is limited, a number of diarrheal disease causing pathogens including E.coli can spread infections mainly through fecally contaminated water [2, 26, 29]. Diarrheal diseases caused by contaminated water alone can be responsible for more than $40 \%$ of deaths in such settings [26]. Activities such as maintaining personal hygiene, practicing good sanitation, managing medical and solid waste etc. are critical in preventing transmission of diseases caused by contamination through the improper storage, handling and transport of food and water and the sharing of cooking utensils $[17,26]$.

However in conflict areas, roads, waterways and other civil amenities may be disrupted thus making the transport of bottled water or of water in tankers to afflicted areas difficult, time consuming, unreliable and expensive. Following the recent civil unrest in Syria, refugee camps across the country were faced with acute water shortages resulting from compromised existing water supply systems. In the Yarmouk refugee camp near Damascus, people have been forced to depend on untreated groundwater obtained from wells. UNWRA medical staff reported that the severe water shortage coupled with crowded living conditions in the camp have led to increase in communicable diseases such as typhoid, scabies and diarrhea [30, 31]. The cholera outbreak in Haiti following the 2010 earthquake is another prime example of the importance of WASH conditions following a natural disaster. The measures to curb the rapid spread of the disease included transporting potable water to temporary shelters through tankers, chlorination of municipal water supplies and distribution of water treatment products [32, 33]. In disaster response as in the case of communities, recontamination of treated water following methods like boiling has been reported [34]. The importance of hygiene and sanitation can again be stressed in such circumstances - researchers investigating a Malawian refugee camp found that though the source water was relatively clean, contamination of water occurred by the hands of the women who collected the water in open rim buckets [35].

Studies examining intervention techniques for water treatment in refugee camps have previously reported success in curbing diarrheal diseases [35, 36]. SODIS in conventional containers is already a recommended method of treating water for affected populations in the wake of humanitarian crises or natural disasters [37]. Scaling up the volume of SODIS containers can prove useful in such settings where water treatment is usually done in bulk and not at a household level. Hence, SODIS in large volumes has the potential to cheaply and simply alleviate the problem related to water shortages in emergency situations - either as a means of water disinfection for consumption where costlier methods cannot be safely implemented or as a means of improving sanitation and hygiene to minimize the spread of fecal contamination.

\section{What are the challenges expected with SODIS in large volumes?}

Based on an extensive literature review, we identified certain key concerns associated with the traditional SODIS method which may likely be carried over into any attempts to implement SODIS in large volumes. We discuss the following four challenges:

- Cold or Cloudy Weather [38]

- The Fear of Leaching in Plastic Bottles [39]

- Water Turbidity [38]

- Community Acceptance [40]

\section{Cold or cloudy weather}

Exposure to sunlight renders pathogens inactive by three possible mechanisms - optical inactivation, thermal inactivation and a synergistic action of both stresses. The synergistic effects that UV radiation and high temperatures have on bacteria have been well documented and this 'combination therapy' is seen to cause rapid drops in 
populations of viable bacteria when the temperature of the water being treated reaches $45^{\circ} \mathrm{C}$ or more $[41,42]$.

Previous work concentrating on the dynamics of SODIS has looked at the effectiveness of small volume reactors under a variety of climatic conditions either through laboratory simulation of climatic conditions or field data. A mathematical solar radiation model constructed using field data in Haiti looked at the practicality of implementing SODIS all year round in the country. This work was carried out in January when the weather was colder and UV intensity less harsh when compared to Haiti's normally tropical climate. 1.5 L PET bottles were used to evaluate the actual rate of bacterial inactivation and it was seen that instead of 5-6 h, a 2 day exposure was necessary to ensure $100 \%$ success in microbial inactivation. The researchers saw no microbial inactivation on days when the incident solar intensity failed to meet the set threshold value, i.e. constant irradiation of $500 \mathrm{~W} / \mathrm{m}^{2}$ for at least $3 \mathrm{~h}$ [43]. Given the synergistic activity of UV radiation and heat, the temperature that the water being treated reaches during exposure is critical. For instance, simulated sunlight experiments carried out on cysts of the protozoa Acanthamoeba polyphaga showed no appreciable reduction in cyst viability for water samples that reached a maximum of $40{ }^{\circ} \mathrm{C}$ over the course of $6 \mathrm{~h}$. Subsequent work carried out by the same group reported a $3.6 \log$ reduction in viable cysts at $50{ }^{\circ} \mathrm{C}$ after $6 \mathrm{~h}$ of treatment whereas a 3.3 $\log$ reduction was observed in only $4 \mathrm{~h}$ following exposure at $55^{\circ} \mathrm{C}[44,45]$.

When implementing SODIS, it is recommended that for best possible results the water to be treated be exposed to total solar irradiation of $500 \mathrm{~W} / \mathrm{m}^{2}$ for about $5 \mathrm{~h}$ [6]. It is worth noting that several developing countries as well as most of the countries with the largest number of refugees and displaced people lie in or close to the global region perceived as being most favourable for SODIS [6, 28, 46]. However, emergency situations such as natural disasters can strike anywhere hence it may hence be necessary to evaluate the daily and seasonal variations in temperature and incident solar radiation on a particular site before the application of SODIS. In cloudy conditions, exposure times of up to $48 \mathrm{~h}$ are recommended for solar radiation levels to adequately disinfect water and under heavy rainfall, the use of SODIS is not recommended [6,43]. Certain additives have shown success in enhancing SODIS' effectiveness and reducing the overall time needed to disinfect water. A combination of SODIS and lime juice added to E.coli contaminated water in PET bottles showed a 5.6 log decrease in microbial cells within half an hour of solar exposure while SODIS alone showed a $1.5 \log$ decrease [7]. Such findings highlight the potential usefulness of using additives to improve confidence in SODIS in situations where the radiation and temperature thresholds are not met. The study which determined the efficacy of WDCs as dependable SODIS vessels was conducted without any supplementation techniques, in the summer with the UV irradiance and temperatures being expectedly high. These conditions achieved a 5-6 log reduction in inoculated bacteria with maximum exposure duration of $6 \mathrm{~h} \mathrm{[16].} \mathrm{Future} \mathrm{research} \mathrm{is} \mathrm{required} \mathrm{on} \mathrm{the} \mathrm{applicability}$ of WDCs and increased water volumes for SODIS treatment under varying climatic conditions and the accompanying temperature and solar intensity variations. Accordingly, the use of additives like limes or other supplementation techniques such as blackening the bottles' surfaces can then be developed $[7,38]$.

\section{The fear of leaching in plastic bottles}

In the past, there have been public concerns about leaching of chemicals such as antimony and phthalates from plastic containers into the food or water they contain [39, 47]. As regards SODIS, Wegelin et al. filled PET bottles, exposed them to sunlight for up to $6 \mathrm{~h}$ and showed no harmful movement of photoproducts into the treated water under temperature and UV exposure encountered in field and laboratory tests [48].

Unlike small volume PET bottles, WDCs are generally made of polycarbonate (PC), a plastic whose main monomer is bisphenol-A (BPA), a chemical that is a known weakly estrogenic endocrine disruptor [49]. Studies have found that high temperatures and reuse can affect the rates of BPA migration from $\mathrm{PC}$ bottles into the water they hold $[50,51]$. Brede et al. tracked the rate of release of BPA from PC baby bottles at elevated temperatures of up to $100{ }^{\circ} \mathrm{C}$ and under conditions of vigorous simulated use which included boiling, dishwashing and brushing at different temperatures. After an observation period of more than $20 \mathrm{~h}$, a detectable amount of BPA was measured, though the levels did not exceed the then established limits for BPA exposure (0.01 mg BPA $/ \mathrm{kg}$ body weight per day) [52]. This data taken together suggests that holding water in PC bottles at elevated temperatures, as would occur under SODIS treatment, would exacerbate the rate of BPA release from the plastic. It is worth noting however that these temperatures and time frames are much higher than those recorded in normal SODIS use. For instance, recent research on bacterial inactivation was carried out using $19 \mathrm{~L} \mathrm{PC}$ large bottles as well as small volume PET bottles in the summer months in three countries - India, Bahrain and Spain. In each location, the bottles were exposed to 5-6 h of uninterrupted natural sunshine and temperatures recorded hourly. The water temperature never crossed $55{ }^{\circ} \mathrm{C}$ in any of the bottles under any of the experimental conditions [16].

Regulatory bodies have cleared the use of BPA in the food and beverage industry because recorded human 
exposure levels are considered too low to be able to cause any adverse health effects in any age group $[53,54]$. Based on most recent evidences, the tolerable daily intake (TDI) for BPA from dietary exposure is $4 \mu \mathrm{g} / \mathrm{kg}$ body weight according to the European Food Safety Authority (EFSA) while the dietary intake in the highest exposure age groups is estimated to be $0.857 \mu \mathrm{g} / \mathrm{kg}$ body weight per day [54]. Separate BPA metabolism studies in rats and humans have shown that following oral exposure, BPA is efficiently expelled from the body and there is no evidence of any appreciable build-up of the chemical in the bloodstream or in the tissue. The human study examined serum BPA concentrations following dietary intake that was much higher than that reported for the general adult U.S. public. Nevertheless, no biologically active BPA was detected at the time of assessment $[55,56]$. In the previously mentioned study by Brede et al., the most extreme case of leaching- with exposure to boiling water, multiple dishwasher cycles and brushing, measured BPA at $8.4 \pm 4 \mu \mathrm{g} / \mathrm{L}$ (average from 12 bottles) [52]. In the light of the figures above on the TDI established by the EFSA, a person weighing $60 \mathrm{~kg}$ would have to consume around $28 \mathrm{l}$ of the BPA tainted water in a single day to cross the tolerable limit (assuming no other dietary source of exposure).

A more recent study conducted using PET and PC bottles found that leaching of antimony and bromine into the water did occur and interestingly, the main contributor to the escape of these chemicals was not range of temperature or UV exposure, but number of times the container was reused. PC bottles reused up to 27 times showed antimony leaching into the water at concentrations of around $17 \mathrm{ng} / \mathrm{L}$ while bromine was measured at around $15 \mathrm{ng} / \mathrm{L}$. These levels were deemed insufficient to cause health concerns in users, however it was also suggested that larger volume bottles may be subjected to harsh cleaning procedures involving high temperatures, cleaning chemicals and mechanical scrubbing and that these factors together could influence the rate of release of harmful additives into the water [57]. This is definitely an area that requires deeper study as it is likely that users of SODIS will reuse the bottles either due to economic reasons or because it would prove inconvenient to procure fresh bottles. Research in this area is of interest to the community as there is a general fear associated with placing plastic bottles under direct sunlight due to leaching of carcinogens that may occur.

\section{Water turbidity}

Turbidity is a factor that varies greatly in water sources from region to region. Highly turbid water reduces the efficiency of solar disinfection by decreasing the penetration of sunlight through the water thus protecting microbes from inactivation. The Swiss Federal Institute of Aquatic Science and Technology (EAWAG) recommend that raw water have a minimum turbidity of 30NTU before being subjected to SODIS treatment [6]. Studies in Kenya have shown that in water samples having turbidity more than 200NTU, around $1 \%$ of the incident UV radiation was able to penetrate the water samples and disinfection occurred mainly by the thermal route when the temperature of the water rose above $55^{\circ} \mathrm{C}$ [4].

Recent investigations on the performance of WDCs compared with PET bottles filled with turbid (100 NTU) water have shown that satisfactory inactivation occurred in both cases though the time of exposure needed for the WDCs was slightly higher [16]. This is encouraging and further work is needed that evaluates SODIS in WDCs singly as well as coupled with turbidity treatments as natural water turbidities can reach as high as 2000 NTU depending on factors such as rainfall [4].

There are several procedures recommended for removal of turbidity in water, including simple settling and filtration. Minerals like Alum (potassium sulphate) and the seeds of plants like Moringa oleifera have been used in water flocculation to reduce turbidity. Both these flocculants have been studied as pre-treatment options to clarify water prior to the use of methods such as chlorination or SODIS and have shown promising results. However, consideration must be given to the fact that addition of any pre-treatment step lengthens the overall time required for disinfection and hence choosing a viable pretreatment method depends very much on factors like local availability of the resource, manpower and cost $[58,59]$. Other factors to consider are the changes in physical characteristics of the water treated; for instance unlike flocculation by alum, the use of M.oleifera seeds does not affect the $\mathrm{pH}$ and conductivity of the water and also generates an appreciably less amount of sludge [60]. However, a stumbling block in the uptake of this turbidity removal method may be the increase in organic content following treatment and the accompanying changes in odour or taste to the water, particularly after storage [61].

\section{Community acceptance}

Barriers to the successful dissemination of SODIS can include ignorance regarding the causes of diarrheal disease, reluctance to put in the time involved in addition to that of a normal workday or during seasonal increases in workloads, and an absence of water sources in close proximity to the user [40,62]. In developing countries, $12 \%$ of households without piped water rely on children below 15 years for collection of drinking water with girls twice as likely to carry this burden as boys. In SubSaharan Africa, more than $25 \%$ of the population takes longer than $30 \mathrm{~min}$ for a single round trip of water collection. Globally, the percentages of households within 15 min of a source of water vary greatly with the most recent data reporting $97 \%$ in Eastern Europe and 54\% 
in Sub-Saharan Africa. Rural households are less likely than urban ones to have a source of water nearby [63]. Field data is needed before recommendations can be made on the communities in which SODIS volume can be scaled up. However, given the above figures on primary water collectors and considering the dimensions and weight of filled WDCs, SODIS on large volumes may prove inconvenient unless the bottles are filled and exposed at or near to the site of use.

Cost of the larger bottles may also be a relevant factor to their uptake in communities and the prices of large plastic bottles vary around the world. In Uganda last year, the unit price of a PET bottle $(2 \mathrm{~L})$ was $0.50 €$ while that of a WDC (19 L) was 6.40€ [16]. Keeping in mind $15 \mathrm{~L}$ as the upper limit of water quantity needed per person per day and assuming no other means of disinfecting water, a single person would spend $4 €$ and need to fully fill and monitor 8 PET bottles to cross this benchmark. A single WDC on the other hand would provide $4 \mathrm{~L}$ more than the recommended volume within a single SODIS treatment time.

Community studies on WDCs are vital because in cases where compliance is high, strong links have been seen between using SODIS and drops in incidences of diarrhea; indeed there is a proven link between long term, faithful adherence to any water treatment method and associated health gains [64]. For instance, in an earlier 6 month study in India, the closely controlled and monitored group of children in the intervention arm (compliance rate $78 \%$ ) showed a $40 \%$ decrease in all diarrheal episodes compared to the non-intervention group [13]. Two other high compliance studies in Cambodia and in South Africa with $95 \%$ and $75 \%$ user compliance, respectively, reported reduced incidences of diarrhea in the intervention groups and also stressed the importance of participant motivation and choosing specific methods of participant allotment into intervention and control groups $[65,66]$.

\section{Conclusions}

Given the minimum requirements of 7.5-15 L of water/ person/day, disinfecting large volumes by methods such as boiling or chlorination may not be cost or labour effective in developing countries or in humanitarian emergencies. Access to sufficient quantities of clean water for hygiene and sanitation can be as important as clean water for consumption when it comes to prevention of communicable diseases. SODIS in large volumes can potentially meet these needs.

We recommend that future research focus on addressing some of the concerns and gaps in research associated with scaling up of SODIS volumes. These include the potential for leaching of plastic additives into treated water, temperature profiles and climatic conditions under which
WDCs perform well and the effectiveness of the method when coupled with pretreatment techniques. Moreover, close attention should be given to studying and developing dissemination procedures that guarantee the highest rates or compliance with SODIS. Social research is also needed to look at acceptance and perceived benefit of the SODIS at the community level, and the role it can play to improve the resilience of communities to social and economic shocks in conflict and post conflict settings.

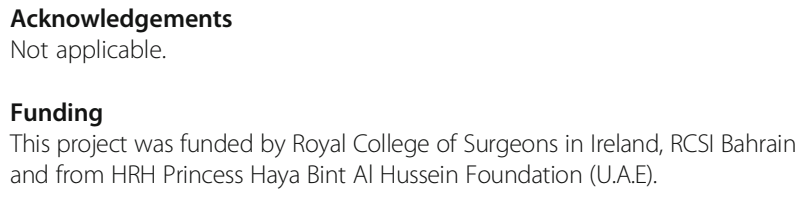

Availability of data and materials

Not applicable.

Authors' contributions

MBK and KE designed and drafted the manuscript. PB, MBK and KE participated in the writing of the manuscript. MBK, KE and KGM revised the manuscript critically. All authors read and approved the final manuscript.

\section{Competing Interests}

The authors declare that they have no competing interests.

\section{Consent for publication}

Not applicable.

Ethics approval and consent to participate

Not applicable.

\section{Author details}

${ }^{1}$ Department of Basic Biomedical Sciences, RCSI, Manama, Bahrain. ${ }^{2}$ Graduate Entry Medical School, University of Limerick, Limerick, Ireland. ${ }^{3}$ Royal College of Surgeons in Ireland, Dublin 2, Ireland.

Received: 16 December 2015 Accepted: 17 August 2016

Published online: 05 September 2016

\section{References}

1. Prüss-Üstün ABR, Gore F, Bartram J. Safer water, better health: costs, benefits and sustainability of interventions to protect and promote health. Geneva: World Health Organization; 2008. http://apps.who.int/iris/bitstream/10665/ 43840/1/9789241596435_eng.pdf. Accessed 22 Nov 2015.

2. World Health Organization. Diarrhoeal disease. 2013. http://www.who.int/ mediacentre/factsheets/fs330/en/. Accessed 10 Mar 2015.

3. Centers for Disease Control and Prevention. Household Water Treatment Options in Developing Countries: Solar Disinfection (SODIS). 2008. http://www. cdc.gov/safewater/publications_pages/options-sodis.pdf. Accessed 23 May 2015.

4. Joyce TM, McGuigan KG, ElmoreMeegan M, Conroy RM. Inactivation of fecal bacteria in drinking water by solar heating. Appl Environ Microbiol. 1996; 62(2):399-402

5. Boyle M, Sichel C, Fernandez-Ibanez P, Arias-Quiroz GB, Iriarte-Puna M, Mercado A, Ubomba-Jaswa E, McGuigan KG. Bactericidal effect of solar water disinfection under real sunlight conditions. Appl Environ Microbiol. 2008;74(10):2997-3001.

6. Meierhofer, R. \& Wegelin, M. Solar water disinfection: A guide for the application of SODIS. SANDEC (Water \& Sanitation in Developing Countries) at EAWAG (Swiss Federal Institute for Environmental Science and Technology). 2002. http://www.sodis.ch/methode/anwendung/ausbildungsmaterial/index_ EN. Accessed 23 Jul 2016.

7. Harding AS, Schwab KJ. Using Limes and Synthetic Psoralens to Enhance Solar Disinfection of Water (SODIS): A Laboratory Evaluation with Norovirus, Escherichia coli, and MS2. Am J Trop Med Hyg. 2012;86(4):566-72.

8. Amin MT, Nawaz M, Amin MN, Han M. Solar Disinfection of Pseudomonas aeruginosa in Harvested Rainwater: A Step towards Potability of Rainwater. Plos One. 2014;9(3):1-10:e90743. doi:10.1371/journal.pone.0090743. 
9. Clasen T, Haller L, Walker D, Bartram J, Cairncross S. Cost-effectiveness of water quality interventions for preventing diarrhoeal disease in developing countries. J Water Health. 2007;5(4):599-608.

10. Meierhofer R, Landolt G. Factors supporting the sustained use of solar water disinfection - Experiences from a global promotion and dissemination programme. Desalination. 2009:248(1-3):144-51.

11. McGuigan KG, Conroy RM, Mosler H-J, du Preez M, Ubomba-Jaswa E, Fernandez-Ibanez P. Solar water disinfection (SODIS): A review from benchtop to roof-top. J Hazard Mater. 2012;235:29-46.

12. Conroy RM, Meegan ME, Joyce T, McGuigan K, Barnes J. Solar disinfection of drinking water protects against cholera in children under 6 years of age. Arch Dis Child. 2001;85(4):293-5.

13. Rose A, Roy S, Abraham V, Holmgren G, George K, Balraj V, Abraham S Muliyil J, Joseph A, Kang G. Solar disinfection of water for diarrhoeal prevention in southern India. Arch Dis Child. 2006:91(2):139-41.

14. Graf J, Togouet SZ, Kemka N, Niyitegeka D, Meierhofer R, Pieboji JG. Health gains from solar water disinfection (SODIS): evaluation of a water quality intervention in Yaounde, Cameroon. J Water Health. 2010;8(4):779-96.

15. Humanitarian charter and minimum standards in disaster response. The Sphere Project. 2011. http://www.ifrc.org/docs/idrl//1027EN.pdf. Accessed 23 Jul 2016.

16. Keogh MB, Castro-Alférez M, Polo-López MI, Fernández Calderero I, Al-Eryan YA, Joseph-Titus C, Sawant B, Dhodapkar R, Mathur C, McGuigan KG, et al. Capability of 19-L polycarbonate plastic water cooler containers for efficient solar water disinfection (SODIS): Field case studies in India, Bahrain and Spain. Sol Energy. 2015;116:1-11.

17. Fewtrell L, Kaufmann RB, Kay D, Enanoria W, Haller L, Colford JM. Water, sanitation, and hygiene interventions to reduce diarrhoea in less developed countries: a systematic review and meta-analysis. Lancet Infect Dis. 2005 5(1):42-52.

18. Pruss-Ustun A CC. Preventing disease through healthy environments. World Health Organization. Geneva. 2006. http://www.who.int/quantifying_ ehimpacts/publications/preventingdisease.pdf?ua=1. Accessed 24 May 2015.

19. Ejemot-Nwadiaro RI EJ, Meremikwu MM, Critchley JA. Hand washing for preventing diarrhoea. Cochrane Database of Systematic Reviews. 2008;(1). Art. No.: CD004265.

20. Dangour AD, Watson L, Cumming O, Boisson S, Che Y, Velleman Y, Cavill S, Allen E, Uauy R. Interventions to improve water quality and supply, sanitation and hygiene practices, and their effects on the nutritional status of children. Cochrane Database of Systematic Reviews. 2013;(8): Art. No.: CD009382.

21. Rosa G, Clasen T. Estimating the Scope of Household Water Treatment in Low- and Medium-Income Countries. Am J Trop Med Hyg. 2010;82(2):289-300.

22. Oswald WE, Lescano AG, Bern C, Calderon MM, Cabrera L, Gilman RH. Fecal Contamination of Drinking Water within Peri-Urban Households, Lima, Peru. Am J Trop Med Hyg. 2007;77(4):699-704.

23. Copeland CC, Beers BB, Thompson MR, Fitzgerald RP, Barrett $L$, Sevilleja JE, Alencar S, Lima AAM, Guerrant RL. Faecal contamination of drinking water in a Brazilian shanty town: importance of household storage and new human faecal marker testing. J Water Health. 2009;7(2):324-31.

24. Quick RE, Venczel LV, Gonzalez O, Mintz ED, Highsmith AK, Espada A, Damian E, Bean NH, De Hannover EH, Tauxe RV. Narrow-Mouthed Water Storage Vessels and in Situ Chlorination in a Bolivian Community: A Simple Method to Improve Drinking Water Quality. Am J Trop Med Hyg. 1996;54(5):511-6.

25. Clasen T, McLaughlin C, Nayaar N, Boisson S, Gupta R, Desai D, Shah N. Microbiological effectiveness and cost of disinfecting water by boiling in semi-urban India. Am J Trop Med Hyg. 2008;79(3):407-13.

26. Connolly MA, Gayer M, Ryan MJ, Salama P, Spiegel P, Heymann DL. Communicable diseases in complex emergencies: impact and challenges. Lancet. 2004;364(9449):1974-83.

27. Dorea CC. Comment on "Emergency water supply: A review of potential technologies and selection criteria.". Water Res. 2012;46(18):6175-6.

28. UNHCR Global Trends 2015. United Nations High Commissioner for Refugees. 2016. http://unhcr.org/556725e69.html. Accessed 23 Jul 2016.

29. Kouadio IK, Aljunid S, Kamigaki T, Hammad K, Oshitani H. Infectious diseases following natural disasters: prevention and control measures. Expert Rev Anti Infect Ther. 2012;10(1):95-104.

30. UNRWA expresses deep concern on water situation in Yarmouk. United Nations Relief and Works Agency for Palestine Refugees in the Near East. 2014. http://www.unrwa.org/newsroom/official-statements/unrwa-expressesdeep-concern-water-situation-yarmouk. Accessed 23 Jul 2016

31. Controlling outbreaks of disease in crowded refugee shelters. United Nations Relief and Works Agency for Palestine Refugees in the Near East.
2014. http://www.unrwa.org/newsroom/features/controlling-outbreaksdisease-crowded-refugee-shelters. Accessed 23 Jul 2016

32. Tappero JW, Tauxe RV. Lessons Learned during Public Health Response to Cholera Epidemic in Haiti and the Dominican Republic. Emerg Infect Dis. 2011;17(11):2087-93.

33. Gelting R, Bliss K, Patrick M, Lockhart G, Handzel T. Water, Sanitation and Hygiene in Haiti: Past, Present, and Future. Am J Trop Med Hyg. 2013;89(4):665-70.

34. Gupta SK, Suantio A, Gray A, Widyastuti E, Jain N, Rolos R, Hoekstra RM, Quick R. Factors associated with E-coli contamination of household drinking water among tsunami and earthquake survivors, Indonesia. Am J Trop Med Hyg. 2007;76(6):1158-62

35. Roberts L, Chartier Y, Chartier O, Malenga G, Toole M, Rodka H. Keeping clean water clean in a Malawi refugee camp: a randomized intervention trial. Bull World Health Organ. 2001;79(4):280-7.

36. Doocy S, Burnham G. Point-of-use water treatment and diarrhoea reduction in the emergency context: an effectiveness trial in Liberia. Trop Med Int Health. 2006:11(10):1542-52.

37. Emergency treatment of drinking water at point-of-use; WHO technical note for emergencies No. 5. World Health Organization. 2005. http://www.who. int/water_sanitation_health/hygiene/envsan/treatmdrwat.pdf?ua=1. Accessed 11 Nov 2015.

38. Sommer B, Marino A, Solarte Y, Salas ML, Dierolf C, Valiente C, Mora D, Rechsteiner R, Setter P, Wirojanagud W, et al. SODIS - An emerging water treatment process. Journal of Water Supply Research and Technology-Aqua. 1997;46(3):127-37.

39. Sax L. Polyethylene Terephthalate May Yield Endocrine Disruptors. Environ Health Perspect. 2010;118(4):445-8.

40. Rainey RC, Harding AK. Acceptability of solar disinfection of drinking water treatment in Kathmandu Valley, Nepal. Int J Environ Health Res. 2005;15(5): 361-72.

41. Wegelin M, Canonica S, Mechsner K, Fleischmann T, Pesaro F, Metzler A Solar water disinfection: Scope of the process and analysis of radiation experiments. Aqua: Journal of Water Supply Research and Technology. 1994:43(3):154-69.

42. McGuigan KG, Joyce TM, Conroy RM, Gillespie JB, Elmore-Meegan M. Solar disinfection of drinking water contained in transparent plastic bottles: characterizing the bacterial inactivation process. J Appl Microbiol. 1998; 84(6):1138-48

43. Oates PM, Shanahan P, Polz MF. Solar disinfection (SODIS): simulation of solar radiation for global assessment and application for point-of-use water treatment in Haiti. Water Res. 2003;37(1):47-54.

44. Lonnen J, Kilvington S, Kehoe SC, Al-Touati F, McGuigan KG. Solar and photocatalytic disinfection of protozoan, fungal and bacterial microbes in drinking water. Water Res. 2005;39(5):877-83.

45. Heaselgrave W, Patel N, Kilvington S, Kehoe SC, McGuigan KG. Solar disinfection of poliovirus and Acanthamoeba polyphaga cysts in water - a laboratory study using simulated sunlight. Lett Appl Microbiol. 2006:43(2):125-30.

46. 2016 Global Report on Internal Displacement (GRID 2016). Internal Displacement Monitoring Centre. Geneva: 2016. http://www.internal-displacement.org/ publications/2016/2016-global-report-on-internal-displacement-grid-2016. Accessed 23 Jul 2016

47. Muncke J. Exposure to endocrine disrupting compounds via the food chain Is packaging a relevant source? Sci Total Environ. 2009:407(16):4549-59.

48. Wegelin M, Canonica S, Alder AC, Marazuela D, Suter MJF, Bucheli TD, Haefliger OP, Zenobi R, McGuigan KG, Kelly MT, et al. Does sunlight change the material and content of polyethylene terephthalate (PET) bottles? Journal of Water Supply Research and Technology-Aqua. 2001;50(3):125-33.

49. Wetherill YB, Akingbemi BT, Kanno J, McLachlan JA, Nadal A, Sonnenscheing C, Watson CS, Zoeller RT, Belcher SM. In vitro molecular mechanisms of bisphenol A action. Reprod Toxicol. 2007;24(2):178-98.

50. Le HH, Carlson EM, Chua JP, Belcher SM. Bisphenol A is released from polycarbonate drinking bottles and mimics the neurotoxic actions of estrogen in developing cerebellar neurons. Toxicol Lett. 2008;176(2):149-56.

51. Nam S-H, Seo Y-M, Kim M-G. Bisphenol A migration from polycarbonate baby bottle with repeated use. Chemosphere. 2010;79(9):949-52.

52. Brede C, Fjeldal P, Skjevrak I, Herikstad H. Increased migration levels of bisphenol A from polycarbonate baby bottles after dishwashing, boiling and brushing. Food Addit Contam. 2003;20(7):684-9.

53. Bisphenol A (BPA): Use in Food Contact Application. U.S. Food and Drug Adminstration. 2014. http://www.fda.gov/food/ingredientspackaginglabeling/ foodadditivesingredients/ucm064437.htm. Accessed 24 May 2015 
54. EFSA CEF Panel (EFSA Panel on Food Contact Materials, Enzymes, Flavourings and Processing Aids). Scientific Opinion on the risks to public health related to the presence of bisphenol A (BPA) in foodstuffs. EFSA J. 2015;13(1):3978.

55. Doerge DR, Twaddle NC, Vanlandingham M, Fisher JW. Pharmacokinetics of bisphenol A in neonatal and adult Sprague-Dawley rats. Toxicol Appl Pharmacol. 2010;247(2):158-65.

56. Teeguarden JG, Calafat AM, Ye X, Doerge DR, Churchwell MI, Gunawan R, Graham MK. Twenty-Four Hour Human Urine and Serum Profiles of Bisphenol A during High-Dietary Exposure. Toxicol Sci. 2011;123(1):48-57.

57. Andra SS, Makris KC, Shine JP. Frequency of use controls chemical leaching from drinking-water containers subject to disinfection. Water Res. 2011;45(20):6677-87.

58. Preston K, Lantagne D, Kotlarz N, Jellison K. Turbidity and chlorine demand reduction using alum and moringa flocculation before household chlorination in developing countries. J Water Health. 2010;8(1):60-70.

59. Wilson SA, Andrews SA. Impact of a natural coagulant pretreatment for colour removal on solar water disinfection (SODIS). Journal of Water Sanitation and Hygiene for Development. 2011;1 (1):57-67.

60. Ndabigengesere A, Narasiah KS, Talbot BG. Active agents and mechanism of coagulation of turbid waters using moringa-oleifera. Water Res. 1995;29(2): 703-10.

61. Ndabigengesere A, Narasiah KS. Quality of water treated by coagulation using Moringa oleifera seeds. Water Res. 1998;32(3):781-91.

62. Christen A, Pacheco GD, Hattendorf J, Arnold BF, Cevallos M, Indergand S, Colford JM, Maeusezahl D. Factors associated with compliance among users of solar water disinfection in rural Bolivia. Bmc Public Health. 2011;11. doi:10.1186/1471-2458-11-210

63. World Health Organization/United Nations Children's Fund. Progress on sanitation and drinking water 2015 update and MDG assessment. 2015. http://apps.who.int/iris/bitstream/10665/177752/1/9789241509145_eng. pdf?ua $=1$. Accessed 22 Nov 2015

64. Brown J, Clasen T. High Adherence Is Necessary to Realize Health Gains from Water Quality Interventions. Plos One. 2012;7(5).

65. du Preez M, McGuigan KG, Conroy RM. Solar Disinfection of Drinking Water In the Prevention of Dysentery in South African Children Aged under 5 Years: The Role of Participant Motivation. Environ Sci Technol. 2010:44(22):8744-9.

66. McGuigan KG, Samaiyar P, du Preez M, Conroy RM. High Compliance Randomized Controlled Field Trial of Solar Disinfection of Drinking Water and Its Impact on Childhood Diarrhea in Rural Cambodia. Environ Sci Technol. 2011:45(18):7862-7.

\section{Submit your next manuscript to BioMed Central and we will help you at every step:}

- We accept pre-submission inquiries

- Our selector tool helps you to find the most relevant journal

- We provide round the clock customer support

- Convenient online submission

- Thorough peer review

- Inclusion in PubMed and all major indexing services

- Maximum visibility for your research

Submit your manuscript at www.biomedcentral.com/submit 